JENJAMINAN MUTU

LEMBAGA PENJAMINAN MUTU

INSTITUT HINDU DHARMA NEGERI

DENPASAR

Volume 5 Nomor 1 Februari 2019

ISSN : 2407-912X (Cetak)

ISSN : 2548-3110 (Online)

http://ejournal.ihdn.ac.id/index.php/JPM

\title{
PROBLEMATIKA PENGAWASAN GURU AGAMA HINDU DALAM PENINGKATKAN MUTU PENDIDIKAN DI KEMENTERIAN AGAMA KOTA DENPASAR
}

\author{
Oleh \\ I Nyoman Temon Astawa \\ Institut Hindu Dharma Negri Denpasar \\ temonastawa@gmail.com
}

diterima 10 Agustus 2019, direvisi 18 Januari 2019, diterbitkan 28 Februari 2019

\begin{abstract}
The Implementation of the Supervision of Hindu Religious Education is an act done by the Supervisors of Hindu Religious Education in order to be able to achieve the established goals, one of the aims is to improve the performance of Hindu Religious Education Teachers in improving the quality of education.

Supervision in improving the performance of Hindu Religious Education Teachers in an effort to improve the quality of education is inseparable from the existence of an action to achieve the goal by utilizing the existing elements. In the supervisory action conducted by the Supervisor of Hindu Education on Hindu Religious Education Teachers, there are factors that hinder the implementation of the Hindu Religious Education Supervisory strategy. Inhibiting factors may arise from the Supervisors of Hindu Religious Education, Hindu Religious Education Teachers, as well as from the policy of supervisors.
\end{abstract}

\section{Keywords: Problematic, quality of education}

\section{PENDAHULUAN}

Pelaksanaan pendidikan terutama pendidikan Agama Hindu masih banyak mengalami kendala-kendala. Salah satunya dari lingkungan pendidik atau guru. Guru merupakan salah satu komponen penting dalam proses pembelajaran. Guru sebagai salah satu anggota organisasi sekolah harus dikelola dengan manajemen yang baik. Kinerja guru dalam upaya peningkatan mutu pendidikan, sangat dipengaruhi pula dukungan sarana dan prasarana seperti : 1) buku pelajaran, 2) media pembelajaran, 3) gedung sekolah, 4) alat tulis dan sebagainya. Sampai saat ini buku-buku pelajaran pendidikan Agama Hindu belum dapat dipenuhi secara maksimal oleh pemerintah bahkan buku-buku pelajaran Agama Hindu sering berubah-ubah. Hal ini belum dicermati oleh guru-guru pendidikan Agama Hindu, 
sehingga proses pembelajaran banyak yang tidak sesuai dengan harapan kurikulum.

Perilaku guru juga tidak terlepas dari kinerja yang dimiliki oleh guru tersebut. Tampaknya ada dua kecendrungan guru dalam menjalankan tugasnya yaitu pertama ada guru yang pertama-tama memikirkan mengenai penghasilan/gaji, memandang pekerjaannya sebagai sarana untuk mendapatkan uang, dan sekolah merupakan organisasi yang menjamin kesejahteraan guru. Dengan demikian guru berupaya memberikan pelajaran tambahan sebanyak mungkin agar mendapatkan tambahan honor sebagaimana yang diaharapkan, guru juga mengajar di sejumlah sekolah agar mendapatkan penghasilan tambahan. Akibatnya prilaku guru seperti itu, guru tidak sempat mempersiapkan pelajaran dengan baik atau memeriksa tugas satu persatu, guru hanyalah mengajar dengan metode mengajar yang mudah dilakukan baginya tanpa memperhatikan apakah siswa-siswanya dapat mengerti dengan materi pelajaran yang diajarkan. Kedua ada perilaku guru yang menaruh perhatian pada perkembangan siswa berupaya menyumbangkan segala kemampuannya untuk kepentingan siswa, guru berupaya membantu siswa yang mempunyai kemampuan belajar yang rendah. Guru menggunakan berbagai metode mengajar agar siswa dapat mengerti materi pelajaran yang diajarkannya. Guru tersebut mempunyai kreativitas merasa puas apabila siswa berhasil dengan baik.

Perilaku guru yang menyimpang dan memberikan pengaruh terhadap kinerjanya tampaknya dapat dilihat pada isu-isu yang sedang berkembang saat ini bahwa diketahui guru yang lolos sertifikasi dan sudah mendapatkan tunjangan serifikasi malah menunjukkan kinerja yang kurang baik, guru tersebut malas untuk memberikan pembelajaran di kelas, hal ini diketahui setelah adanya pengawas pendidikan berkunjung ke sekolah (Bali Post, 2017).

Kepemimpinan kepala sekolah juga merupakan salah satu yang menentukan kinerja guru. Faktor perilaku kepemimpinan mempengaruhi kinerja bawahannya. Makin efektif kepemimpinan seseorang maka makin tinggi pula kinerja bawahannya atau sebaliknya. Oleh karena seorang kepala sekolah adalah seseorang pemimpin, inovator ataupun seorang supervisor, maka kualitas kepemimpinannya merupakan kunci keberhasilan kinerja bawahan dan bermuara kepada output dan outcome yang berkualitas. Kepemimpinan kepala sekolah merupakan salah satu kekuatan efektif dalam pengelolaan sekolah yang bertanggung jawab dalam menghadapi perubahan dan memperbaiki mutu pendidikan. Mutu pendidikan disuatu lembaga pendidikan dan jenjang pendidikan sangat tergantung kepada pemimpin sekolah. Ini berarti kepala sekolah sebagai pemimpin di suatu sekolah, pola kepemimpinannya sangat mempengaruhi dan menentukan kinerja bawahannya terutama kinerja guru. Oleh karena itu, untuk peningkatan kinerja guru pemimpin harus memperbaiki perilaku kepemimpinannya, menyesuaikan gaya kepemimpinannya dengan situasi yang ada yaitu kemampuan dan kemauan guru, sehingga guru mau meningkatkan kinerjanya dan selalu ingin mencapai hasil yang lebih baik dari sebelumnya.

\section{PEMBAHASAN}

Faktor penghambat pelaksanaan Pengawasan Pendidikan Agama Hindu di Kementerian Agama Kota Denpasar dalam upaya peningkatan kinerja Guru Pendidikan Agama Hindu dapat diuraikan sebagai berikut.

\section{Faktor Penghambat dilihat dari Kondisi Pengawas Pendidikan Agama Hindu}

Faktor Penghambat dilihat dari Kondisi Pengawas Pendidikan Agama Hindu dapat di dibagi menjadi faktor internal dan faktor eksternal. Adapun yang menjadi faktor internal adalah kualifikasi dan pengalaman kerja Pengawas yang tidak berlatar belakang di bidang Pendidikan Agama Hindu, sedangkan faktor eksternal dapat dilihat dari sarana kerja pengawas yang tidak memadai. Berikut diuraikan secara terurut mengenai kualifikasi dan pengalaman kerja Pengawas 
yang tidak berlatar belakang di bidang Pendidikan Agama Hindu, serta sarana kerja Pengawas Pendidikan Agama Hindu yang tidak memadai.

\subsection{Kualifikasi dan Pengalaman Kerja Pengawas yang Tidak Berlatar Belakang Pendidikan Agama Hindu}

Kementerian Agama Kota Denpasar memiliki Pengawas Pendidikan Agama Hindu yang di antaranya adalah Pengawas Pendidikan Agama Hindu tingkat Sekolah Menengah Pertama. Disamping jumlah pengawas yang hanya satu orang Pengawas Pendidikan Agama Hindu tersebut tidak berkualifikasi dan berpengalaman kerja di bidang Pendidikan Agama Hindu. Hal ini tentunya menjadi penghambat pelaksanaan strategi Pengawas di Kementerian Agama Kota Denpasar terutama pada awal diangkatnya calon pengawas yang tidak berlatar belakang Pendidikan Agama Hindu menjadi Pengawas Pendidikan Agama Hindu. Pengawas Pendidikan Agama Hindu yang tidak berlatar belakang Pendidikan Agama Hindu, pada awal kerjanya tentu kurang dapat memahami pelaksanaan kerjanya terutama terkait dengan kelengkapan pembelajaran seperti program pembelajaran, rencana pelaksanaan pembelajaran, dan silabus.

Lebih lanjut mengenai standar kualifikasi Pengawas Pendidikan khususnya Pendidikan Agama Hindu dalam Peraturan Menteri Agama Republik Indonesia No. 16 tahun 2010 tentang Pengelolaan Pendidikan Agama pada Sekolah pasal 20 disebutkan bahwa Pengawas Pendidikan Agama harus memenuhi persyaratan sebagai berikut:

1. Untuk TK dan SD sekurangkurangnya memiliki kualifikasi akademik Strata 1/Diploma IV dari perguruan tinggi yang terakreditasi dan memiliki sertifikat pendidik sebagai guru pendidikan agama di TK dan SD dengan pengalaman kerja minimum 8 tahun atau pengalaman sebagai kepala TK atau SD minimum 4 tahun.
2. Untuk SMP, SMA, dan SMK sekurang-kurangnya memiliki kualifikasi akademik Strata 2 kependidikan dengan ijazah Strata 1 dalam pendidikan agama dari perguruan tinggi yang terakreditasi dan memiliki sertifikat pendidik sebagai guru pendidikan agama di SMP, SMA, dan SMK dengan pengalaman kerja minimum 8 tahun atau pengalaman sebagai kepala SMP, SMA, dan SMK minimum 4 tahun.

3. Memiliki pangkat sekurangkurangnya peñata, golongan ruang $\mathrm{III} / \mathrm{c}$.

4. Berusia maksimal 50 tahun sejak diangkat sebagai pengawas pendidikan agama.

5. Memenuhi kompetensi sebagai pengawas pendidikan agama yang dapat diperoleh melalui uji kompetensi dan/atau pendidikan dan pelatihan fungsional pengawas, pada lembaga yang ditetapkan pemerintah

6. Lulus seleksi pengawas pendidikan agama.

Berdasarkan uraian di atas tampaknya pemilihan Pengawas Pendidikan di Kementerian Agama Kota Denpasar belum dapat dikatakan sesuai dengan ketentuan yang ada. Pemilihan calon Pengawas Pendidikan di Kementerian Agama Kota Denpasar hanya berdasarkan kebijakan khusus yang ditetapkan oleh Pejabat yang ditunjuk dalam wilayah Kementerian Agama Kota Denpasar. Dalam hal ini Kementerian Agama pusat dan kantor wilayah sebagai yang mengawasi Pengawas Pendidikan Agama Hindu belum secara cermat mengetahui hal tersebut, sehingga keadaan ini menjadi penghambat pelaksanaan strategi Pengawas Pendidikan Agama Hindu. Pengawas yang tidak sesuai dengan standar yang telah ditetapkan khususnya Pengawas Pendidikan Agama Hindu yang tidak berkualifikasi dan berpengalaman kerja di bidang Pendidikan Agama Hindu tentunya 
harus bekerja keras untuk memahami kompetensinya dibidang supervisi akademik maupun manajerial agar dapat melaksanakan tugasnya dengan baik.

\subsection{Sarana Kerja Pengawas Pendidikan Agama Hindu Tidak Memadai}

Faktor penghambat sarana kerja Pengawas Pendidikan Agama Hindu dapat dilihat dari kurangnya perlengkapan operasional untuk Pengawas Pengawas Pendidikan Agama Hindu yang tersedia di Kementerian Agama Kota Denpasar. Para Pengawas Pendidikan Agama Hindu tentunya memerlukan sarana untuk menunjang pencapaian tujuan pelaksanaan program kerja Pengawas Pendidikan Agama Hindu. Moenir (1992 : 119) mengemukakan bahwa sarana merupakan segala jenis peralatan, perlengkapan kerja dan fasilitas yang berfungsi sebagai alat utama atau pembantu dalam pelaksanaan pekerjaan, dan juga dalam rangka kepentingan yang sedang berhubungan dengan organisasi kerja.

Pernyataan di atas jelas memberi arah bahwa sarana merupakan seperangkat alat yang digunakan dalam suatu proses kegiatan baik alat tersebut adalah merupakan peralatan pembantu maupun peralatan utama, yang keduanya berfungsi untuk mewujudkan tujuan yang hendak dicapai.

Kurangnya perlengkapan operasional untuk Pengawas Pendidikan Agama Hindu di Kementerian Agama Kota Denpasar adalah: (1) kurangnya kendaraan dinas yang dipergunakan Pengawas Pendidikan Agama Hindu dalam memonitoring guru ke sekolahsekolah, dan (2) belum adanya fasilitas komputer dalam ruang kerja Pengawas Pendidikan Agama Hindu. Untuk lebih jelasnya mengenai faktor penghambat dari sarana Pengawas Pendidikan Agama Hindu di Kementerian Agama Kota Denpasar maka dapat diuraikan sebagai berikut.

\subsubsection{Kurangnya Fasilitas Kendaraan Bagi Pengawas Pendidikan Agama Hindu}

Perlengkapan dalam pelaksanaan operasional Pengawas Pendidikan Agama
Hindu di Kementerian Agama Kota Denpasar tampaknya kurang memadai, khususnya dalam pengadaan kendaraan sepeda motor dinas bagi pengawas Pendidikan Agama Hindu tingkat Sekolah Menengah Pertama. Kendaraan sepeda motor dirasakan penting bagi Pengawas untuk menjalankan tugas, khususnya untuk memonitoring kinerja Guru ke sekolahsekolah. Kenyataan yang ada jumlah kendaraan tidak sesuai dengan jumlah Pengawas Pendidikan Agama Hindu, sehingga mengakibatkan para Pengawas Pendidikan Agama Hindu yang tidak mendapatkan kendaraan merasa kurang optimal dalam menjalankan tugasnya.

Merasa kurangnya kendaraan, para Pengawas Pendidikan Agama Hindu sudah mencoba untuk mengajukan pengadaan kendaraan bagi pengawas ke pusat sebanyak jumlah pengawas yang belum mendapatkan kendaraan. Permohonan tersebut direspon baik oleh pihak pusat, tetapi kenyataannya pengiriman kendaraan dari pusat kurang dari jumlah pengawas yang belum mendapatkan kendaraan, sehingga pengadaan kendaraan bagi Pengawas Pendidikan Agama Hindu masih dirasakan kurang.

Kurangnya kendaraan untuk para Pengawas Pendidikan Agama Hindu ini mengakibatkan pembagian biaya transportasi (pembelian BBM) untuk para Pengawas Pendidikan Agama Hindu juga tidak merata. Biaya transportasi hanya diberikan kepada para Pengawas Pendidikan Agama Hindu yang mendapatkan kendaraan saja, dengan kata lain besarnya biaya BBM (bahan bakar minyak) diberikan sebanyak jumlah kendaraan saja.

Terkait dengan pernyataan tersebut di atas, Supriyono (1999:16) menyatakan bahwa: "biaya merupakan suatu komponen yang sangat penting dalam menunjang pelaksanaan kegiatan dalam usaha mencapai tujuan". Tujuan itu dapat tercapai apabila biaya yang dikeluarkan sebagai bentuk suatu pengorbanan telah diperhitungkan secara tepat.

Beranjak pada uraian di atas pembagian biaya pengganti BBM untuk 
Pengawas Pendidikan Agama Hindu dirasakan kurang tepat. Para Pengawas Pendidikan Agama Hindu yang tidak mendapatkan kendaraan mestinya mendapatkan biaya pengganti BBM juga. Dengan demikian dapat dikatakan besarnya biaya pengganti BBM yang didapatkan oleh para Pengawas Pendidikan Agama Hindu kurang sesuai dengan pelaksanaan tugas Pengawas Pendidikan Agama Hindu. Hal ini dapat mengakibatkan kurangnya kinerja Pengawas Pendidikan Agama Hindu yang tentunya berpengaruh terhadap kinerja Guru Pendidikan Agama Hindu yang dibinanya.

\subsubsection{Belum Adanya Fasilitas Yang memadai di Ruangan Pengawas Pendidikan Agama Hindu}

Kementerian Agama Kota Denpasar sudah memiliki ruangan khusus untuk Pengawas Pendidikan Agama Hindu yang terletak di lantai dua yang berdampingan dengan ruangan Seksi Pendidikan Agama Hindu, namun ruangan tersebut tampaknya belum ada fasilitas komputer dan printer sebagai penunjang pelaksanaan tugas Pengawas Pendidikan Agama Hindu terutama untuk penyusunan perencanaan dan pembuatan laporan pengawas. Terkait dengan hal tersebut hasil wawancara dan observasi dilapangan didapatkan bahwa adanya komputer bagi para Pengawas Pendidikan Agama Hindu dirasakan penting untuk membantu tugas Pengawas Pendidikan Agama Hindu namun kenyataannya memang para Pengawas Pendidikan Agama Hindu belum memiliki sarana komputer di ruang kerjanya. Pengadaan komputer untuk para Pengawas Pendidikan Agama Hindu sudah direncanakan, namun karena keterbatasan anggaran yang dimiliki maka belum dapat direalisasikan untuk sementara, sehingga untuk saat ini para Pengawas Pendidikan Agama Hindu belum memiliki sarana komputer di ruang kerjanya.

Mengacu pada hal di atas, belum adanya fasilitas komputer di ruang kerja Pengawas Pendidikan Agama Hindu di Kementerian Agama Kota Denpasar diakibatkan karena keterbatasan anggaran yang dimiliki. Para Pengawas Pendidikan Agama Hindu berkoordinasi dengan Kasi Pendidikan Agama Hindu sebagai yang membawahi pengawas untuk mengajukan apa saja yang diperlukan oleh para Pengawas Pendidikan Agama Hindu. Permohonan tersebut tampaknya belum dapat dipenuhi secara maksimal karena anggaran yang dimiliki belum mencukupi. Adanya anggaran dirasakan sangat penting, karena mempengaruhi untuk pengadaan sarana prasarana.

Belum adanya fasilitas komputer dalam ruangan Pengawas Pendidikan Agama Hindu tampaknya kurang dapat meningkatkan kompetensi Pengawas Pendidikan Agama Hindu dibidang pengembangan teknologi. Dalam Permendiknas RI No. 12 Tahun 2007 tentang Standar Pengawas Sekolah/Madrasah, kompetensi yang harus dimiliki seorang pengawas sekolah salah satunya adalah memahami konsep teori dan teknologi serta memiliki rasa ingin tahu akan hal-hal baru tentang pendidikan dan ilmu pengetahuan, teknologi dan seni yang menunjang tugas pokok dan tanggungjawabnya.

Beranjak dari uraian di atas, belum adanya fasilitas komputer dan printer untuk Pengawas Pendidikan Agama Hindu mengharuskan para Pengawas Pendidikan Agama Hindu untuk memanfaatkan komputer pribadi dan jasa pengetikan. Pengawas yang memiliki inisiatif untuk memakai komputer pribadinya tentu memiliki kompetensi dibidang pengembangan teknologi, sedangkan pengawas yang memanfaatkan jasa pengetikan belum dapat mengembangkan kompetensinya dibidang teknologi. Selain itu dengan keadaan tersebut para pengawas juga mengeluarkan dana pribadinya untuk pembuatan Laporan Pengawasan. Keadaan yang seperti ini mengharuskan Pengawas Pendidikan Agama Hindu mengeluarkan dana pribadinya dikarenakan tidak adanya biaya pembuatan Laporan Pengawasan di Kementerian Agama Kota Denpasar, padahal jika dirinci perlunya biaya pembuatan laporan tersebut dapat dipergunakan untuk 
pengetikan, print out, penjilidan sampai dengan memperbanyak laporan untuk disetor dan arsip. Dengan demikian tanpa adanya fasilitas komputer untuk Pengawas Pendidikan Agama Hindu akan berpengaruh pada kinerja dan kompetensi Pengawas Pendidikan Agama Hindu yang tentunya akan menghambat peningkatan kinerja Guru Pendidikan Agama Hindu.

\section{Faktor Penghambat dilihat dari Kondisi Guru Pendidikan Agama Hindu}

Pelaksanaan Program Pengawas di Kementerian Agama Kota Denpasar tentunya melibatkan seluruh Guru Pendidikan Agama Hindu yang ada di kawasan Kota Denpasar, sehingga tidak dipungkiri hambatan dalam pelaksanaan Program Pengawas Pendidikan Agama Hindu di Kementerian Agama Kota Denpasar dapat timbul dari kondisi Guru Pendidikan Agama Hindu di kawasan Kota Denpasar. Untuk lebih jelas mengenai hambatan yang ditimbulkan oleh Guru Pendidikan Agama Hindu di Kota Denpasar dapat diuraikan sebagai berikut.

\subsection{Wawasan dan Potensi Guru Pendidikan Agama Hindu Tidak Sama}

Wawasan dan potensi guru yang berbeda-beda di Sekolah Menengah Pertama se-Kota Denpasar mengakibatkan Pengawas Pendidikan Agama Hindu di Kementerian Agama Kota Denpasar kesulitan memberikan pembinaan terkait dengan pelaksanaan Program Pengawasan.

Berdasarkan data dan hasil wawancara di lapangan didapatkan bahwa untuk mencapai tujuan Program Pengawasan Pendidikan Agama Hindu, Guru Pendidikan Agama Hindu tingkat Sekolah Menengah Pertama ikut terlibat di dalam pelaksanaannya. Kualifikasi, kompetensi, serta pengalaman kerja Guru Pendidikan Agama Hindu di Kota Denpasar berbedabeda. Kualifikasi, kompetensi, serta pengalaman kerja guru Pendidikan Agama Hindu yang berbeda-beda mengakibatkan pemahaman masing-masing guru terhadap pelaksanaan Program Pengawasan yang diarahkan oleh para Pengawas Pendidikan Agama Hindu juga tidak sama antara guru yang satu dengan yang lainnya.

Mengenai kualifikasi dan kompetensi guru, pemerintah menetapkan dalam Peraturan Menteri Pendidikan Nasional Republik Indonesia Nomor 16 Tahun 2007 disebutkan bahwa: Guru pada SMP, atau bentuk lain yang sederajat, harus memiliki kualifikasi akademik pendidikan minimum sarjana (S1) dalam bidang pendidikan itu atau psikologi yang diperoleh dari program studi yang terakreditasi. Sedangkan kompetensi yang harus dimiliki guru adalah kompetensi pedagogik, kepribadian, sosial, dan profesional. Keempat kompetensi tersebut terintegrasi dalam kinerja guru.

Beranjak dari uraian di atas, seorang guru memiliki standar kualifikasi dan kompetensi. Guru yang sadar dengan standar kualifikasi dan kompetensi guru khususnya Guru Pendidikan Agama Hindu akan mengembangkan dirinya agar memenuhi standar kualifikasi dan kompetensi guru yang telah ditetapkan, sedangkan guru yang kurang paham atau tidak menghiraukan standar yang telah ditetapkan akan bersikap acuh tak acuh yang tentunya berpengaruh terhadap kinerjanya.

Menurut data Kementerian Agama Kota Denpasar, seluruh Guru Pendidikan Agama Hindu khususnya tingkat Sekolah Dasar di kawasan Kota Denpasar belum semua berkualifikasi S1, Guru Pendidikan Agama Hindu dengan tamatan PGAH sebanyak 7 orang, D2 sebanyak 18 orang, D3 sebanyak 4 Orang, S1 sebanyak 317 orang, dan S2 sebanyak 11 orang, yang tentunya memiliki masa kerja yang berbeda-beda, inilah yang menyebabkan wawasan dan potensi guru berbeda-beda.

Terkait dengan uraian di atas wawasan dan potensi Guru Pendidikan Agama Hindu yang berbeda-beda tersebut dapat menjadi salah satu faktor penghambat para Pengawas Pendidikan Agama Hindu dalam pelaksanaan Program Pengawasan. Guru Pendidikan Agama Hindu yang mengerti akan tugasnya, memiliki wawasan 
serta berpengalaman akan cepat membantu pelaksanaan Program Pengawasan dengan menyiapkan kelengkapan pembelajarannya seperti adanya Program Pembelajaran, Rencana Pelaksanaan Pembelajaran dan silabus. Sebaliknya Guru Pendidikan Agama Hindu yang tidak mengerti akan tugasnya serta kurang berpengalaman mengharuskan para Pengawas Pendidikan Agama Hindu untuk memberikan pembinaan, pengarahan serta pengawasan yang lebih untuk dapat menunjang tercapainya tujuan Program Pengawasan terlebih lagi untuk meningkatkan kinerja Guru Pendidikan Agama Hindu.

\subsection{Penguasaan di Bidang Teknologi}

Seiring dengan berjalannya waktu, perkembangan di bidang teknologi semakin berkembang pesat. Teknologi apabila dipergunakan dengan baik akan menimbulkan manfaat yang berguna diberbagai bidang. Dilihat dari sisi positifnya, teknologi dapat dimanfaatkan dalam dunia pendidikan khususnya membantu guru dalam proses pembelajaran di kelas maupun administrasi guru.

Penggunaan teknologi dalam proses pembelajaran dapat dimanfaatkan sebagai media pembelajaran. Manfaat teknologi dalam dunia pendidikan adalah sebagai berikut.

1. Memperjelas penyajian pesan agar tidak terlalu verbalistis (tahu kata-katanya, tetapi tidak tahu maksudnya)

2. Mengatasi keterbatasan ruang, waktu dan indera.

3. Dengan menggunakan teknologi atau media pembelajaran yang tepat dan bervariasi dapat mengatasi sikap pasif siswa.

4. Dapat menimbulkan persepsi yang sama terhadap suatu masalah (Harjanto, 1997:245).

Berdasarkan uraian di atas adanya teknologi dalam pendidikan sebagai media pembelajaran dirasakan sangat bermanfaat bagi guru. Para Guru Pendidikan Agama Hindu di kawasan Kota Denpasar tentunya dapat memanfaatkan kemajuan teknologi sebagai alat bantu dalam proses pembelajaran pendidikan Agama Hindu di kelas. Materi ajar Pendidikan Agama Hindu tingkat Sekolah Menengah Pertama dapat disajikan menarik dengan Power Point yang ditampilkan melalui LCD (Liquid Crystal Display), sehingga penyajian pesan dengan mudah dapat dipahami oleh siswa serta dapat mengatasi keterbatasan ruang, waktu, dan indera. Hanya saja dengan pesatnya perkembangan teknologi ini, sebagian besar Guru Pedidikan Agama Hindu di kawasan Kota Denpasar kurang dapat mengaplikasikan teknologi melalui media pembelajaran Agama Hindu.

Menurut data observasi dan wawancara di lapangan didapatkan bahwa sebagian besar Guru Pendidikan Agama Hindu di Kota Denpasar belum dapat mengikuti kemajuan teknologi secara maksimal, terutama guru yang berumur 50 tahun ke atas. Pengawas Pendidikan Agama Hindu mengetahui hal ini karena ketika memonitoring guru di kelas belum terlihat penggunaan teknologi sebagai media pembelajaran Agama Hindu, serta belum adanya sarana media pembelajaran berupa komputer atau laptop, dan LCD di sekolah itu.

Mengacu pada hasil di atas, Guru Pendidikan Agama Hindu di kawasan Kota Denpasar yang berumur 50 tahun ke atas tampaknya belum terbiasa menggunakan komputer, laptop dan LCD sebagai alat untuk membantu proses pembelajaran di kelas, karena kurangnya penguasaan terhadap penggunaan komputer, laptop dan LCD, selain itu dilihat dari faktor fisiologis Guru Pendidikan Agama Hindu terutama yang berumur 50 tahun ke atas kurang mampu untuk bekerja di depan komputer dan laptop terlalu lama karena penglihatan yang mulai melemah. Belum adanya sarana komputer, laptop dan LCD khususnya di sekolah-sekolah juga menjadi salah satu faktor beberapa Guru Pendidikan Agama Hindu tidak dapat menguasai sarana teknologi tersebut. 
Mencermati keadaan pembelajaran pendidikan Agama Hindu di kawasan Kota Denpasar, tampak bahwa guru pendidikan Agama Hindu masih menggunakan pembelajaran konvensional yang belum menggunakan sarana teknologi dalam pembelajaran Agama Hindu. Terkait dengan administrasi guru dan pelaporan guru khususnya Guru Pendidikan Agama Hindu yang penyelesaiannya tidak pernah lepas dari penggunaan komputer juga menghambat kerja guru yang kurang penguasaan dengan pemakaian komputer. Guru Pendidikan Agama Hindu yang kurang menguasai komputer terpaksa harus mengandalkan kerja Tata Usaha sekolah untuk menyelesaikan administrasi dan pelaporan guru pendidikan agama Hindu yang nantinya disetor ke Kementerian Agama Kota Denpasar.

Mengenai penguasaan di bidang teknologi, dalam Undang-undang No. 14 tahun 2005 tentang Guru dan Dosen pasal 20 disebutkan bahwa: "dalam melaksanakan tugas keprofesionalan, guru berkewajiban meningkatkan dan mengembangkan kualifikasi akademik dan kompetensi secara berkelanjutan sejalan dengan perkembangan ilmu pengetahuan, teknologi, dan seni". Lebih lanjut Tilaar (1999:205) berpendapat bahwa, melalui penguasaan ilmu pengetahuan dan teknologi yang kuat seorang guru profesional akan menginspirasi anak didiknya dengan ilmu dan teknologi.

Mengacu dari uraian di atas seorang guru yang profesional berkewajiban untuk selalu mengembangkan dirinya dalam ilmu pengetahuan dan teknologi, sehingga dalam pengerjaan administrasi dan pelaporan tidak lagi terlalu bergantung dengan Tata Usaha Sekolah. Pekerjaan Tata Usaha sekolah yang sangat banyak mengharuskan Guru Pendidikan Agama Hindu menunggu giliran untuk dapat dibantu oleh Tata Usaha Sekolah, sehingga administrasi dan pelaporan yang nantinya di setor penyelesaiannya akan memakan waktu yang lama. Dengan demikian Guru Pendidikan Agama Hindu yang kurang menguasai di bidang teknologi khususnya dalam penggunaan komputer, dan hanya mengandalkan Tata Usaha sekolah untuk menyelesaikan segala administrasi dan pelaporannya dapat menghambat pelaksanaan program kerja para Pengawas Pendidikan Agama Hindu, karena Pengawas Pendidikan Agama Hindu membutuhkan data administrasi dan laporan dari Guru Pendidikan Agama Hindu.

\section{Faktor Kebijakan}

Kebijakan menurut Frederock (dalam Wahab, 1991:13) diartikan sebagai suatu tindakan yang mengarah kepada tujuan yang diusulkan oleh seseorang, kelompok atau pemerintah dalam lingkungan tertentu sehubungan dengan adanya hambatanhambatan tertentu, seraya mencari peluangpeluang untuk mencapai tujuan atau mewujudkan sasaran yang dinginkan.

Faktor kebijakan yang diberikan kepada pengawas diantaranya dalam hal pedoman penyusunan Laporan Pengawasan yang diberikan oleh pusat ke Kementerian Agama Kota Denpasar. Pengawas Pendidikan Agama Hindu di Kementerian Agama Kota Denpasar merasa kesulitan. Hal itu disebabkan karena buku pedoman pembuatan laporan pengawasan dari pusat biasanya hanya diberikan kepada salah satu Pengawas Pendidikan Agama Hindu yang mengikuti pelatihan di Kementerian Agama Propinsi Bali. Sehingga tidak semua Pengawas Pendidikan Agama Hindu di Kementerian Agama Kota Denpasar memiliki buku pedoman untuk pembuatan laporan pengawasan. Hambatan yang dihadapi pengawas pendidikan Agama Hindu terletak pada penyusunan pedoman laporan pengawasan pendidikan agama Hindu yang diberikan oleh pusat seperti penyusunan membuat karya ilmiah, sehingga para pengawas merasa kesulitan untuk membuat Laporan Pengawasan tersebut.

Berdasarkan persoalan tersebut menyebabkan para Pengawas Pendidikan Agama Hindu merasa kesulitan dalam penyusunan Laporan Pengawasan, dikarenakan pedoman penyusunan laporan pengawasan yang diberikan oleh pusat ke Kementerian Agama Kota dirasakan seperti 
membuat laporan karya ilmiah, dan tidak semua Pengawas Pendidikan Agama Hindu memiliki Buku Pedoman Pengawasan tersebut, sehingga Pengawas Pendidikan Agama Hindu tidak dapat mempelajarinya secara mendalam. Hal ini mengakibatkan Koordinator Pengawas Pendidikan Agama Hindu memberikan kebijakan dalam penyusunan laporan pengawasan. Hal mana yang dirasa dapat untuk diikuti dalam pedoman penyusunan laporan tersebut, itu saja yang dicantumkan dalam Laporan Pengawasan, sedangkan para Pengawas Pendidikan Agama Hindu yang merasa mampu mengikuti pedoman penyusunan Laporan Pengawas Pendidikan Agama Hindu tersebut membuat laporannya sesuai dengan pedoman yang diberikan oleh pusat, yang pada akhirnya setelah disetorkan ke Kantor Kementerian Agama Provinsi Bali, Laporan Pengawasan tersebut dapat diterima.

\section{KESIMPULAN}

Seorang pemimpin harus mempunyai kemampuan yang dapat diandalkan apapun bentuknya untuk merespon dan menanggulangi permasalahan yang dihadapi, dengan memperhatikan sumber daya yang dimiliki serta menerima masukan atau usulan dari seseorang atau kelompok, sehingga ada jalan keluar yang terbaik, dihasilkan melalui proses yang adil. Terkait dengan faktor kebijakan ini yang demikian dirasakan kurang mampu untuk menanggulangi kesulitan Pengawas Pendidikan Agama Hindu dalam penyusunan laporan pengawasan, sehingga mengakibatkan penyusunan Laporan Pengawasan Pendidikan Agama Hindu di Kementerian Agama Kota Denpasar berbeda-beda antara pengawas yang satu dengan yang lainnya. Dengan demikian hal ini dapat menjadi hambatan para Pengawas Pendidikan Agama Hindu dalam pelaksanaan maupun pembuatan laporan Pengawasan karena Pengawas Pendidikan Agama Hindu belum memiliki kepastian yang benar dalam penyusunan Laporan Pengawasan, atau dapat dikatakan belum ada pedoman yang baku.

\section{Daftar Pustaka}

Elsbree, Willand S., Harold J. Mc. Nally and Richard Wyne, 1987. Elementary School Administration and Supervision, Third Edition, New York: American Book Company.

Dahar, R.W. 1989. Teori-Teori Belajar. Jakarta: Erlangga.

Darma, Agus. 1985. Manajemen Prestasi Kerja. Jakarta: PT Rajawali Press.

Departemen Pendidikan dan Nasional. 2008.

Kamus Besar Bahasa Indonesia.

Jakarta: PT Gramedia Pustaka Utama.

Departemen Pendidikan dan Nasional. 2010. Penyusunan Program Pengawasan Sekolah. Jakarta: Direktorat Jenderal Peningkatan Mutu Pendidik dan Tenaga Kependidikan.

Depdiknas. 2007. Peraturan Menteri

Pendidikan Nasional Republik Indonesia Nomor 12 Tahun 2007 Tentang Standar Pengawas Sekolah. Jakarta: Direktorat Jenderal Peningkatan Mutu Pendidik dan Tenaga Kependidikan.

Nurkolis. 2003. Manajemen Berbasis Sekolah. Jakarta: Grasindo.

Ormston, M dan Shaw, M. 1994. Inspection:

Preparation Guide for School.

London: Logman Group.

Pudja, G. 2005. Bhagawad Gita (Pancama $V e d a)$. Surabaya: Paramita

Rahman, Arief. 2006. Guru Powerful, Guru Masa Depan, Jakarta: Rineka Cipta.

Sudarsana, I. K. (2018). Pengaruh Model Pembelajaran Kooperatif Terhadap Peningkatan Mutu Hasil Belajar Siswa. Jurnal Penjaminan Mutu, 4(1), 20-31.

Wahab, Solichin Abdul. 1991. Analisa Kebijakan: Dari Formulasi ke Implementation. Jakarta: PT. Bumi Aksara.

Wahjosumidjo, 2003, Kepemimpinan Kepala Sekolah. Jakarta: PT Raja Grafindo Persada.

Wahyudin, Din. 1995. Monitoring dan Evaluasi Petunjuk bagi Para Pelaksana. Jakarta: PEQIP. 